\title{
Smoking, Discount Rates, and Returns to Education
}

\author{
Josef Fersterer
}

University of Linz, Austria

\section{Rudolf Winter-Ebmer}

University of Linz, Austria

CEPR, London, IZA, Bonn and WIFO, Vienna

January 2000

This research was inspired by very helpful discussions with Ian Walker and comments by Andrea Ichino. Financial support from the European Commission under the TSER program PL980182 for the PURE project as well as helpful comments by seminar participants at Linz is gratefully acknowledged. 


\section{$\underline{\text { Abstract }}$}

Individual time preference determines schooling enrolment. Moreover, smoking behavior in early ages has been shown to be highly related to time preference rates. Accordingly, we use smoking at age 16 as an instrument for schooling in order to cope with ability bias in a returns to education regression. Doing this for Austrian cross-sectional data, we find no evidence of ability bias.

JEL: J31, I22

Keywords: Returns to education, Instrumental Variables, Ability bias, Discount rates. 


\section{Introduction}

The estimation of returns to education suffers from a typical problem of evaluation research: as an individual cannot be observed in the counterfactual situation with different educational attainment, wages of different persons with similar characteristics - but different schooling - have to be compared. However, forward looking individuals will choose the optimal amount of schooling based on potential earnings and costs of schooling, leading to an endogeneity problem of the schooling variable. A particular concern is "ability bias": individuals with high ability may choose more years of schooling. If ability as such fosters earnings, the OLS returns to education can be seriously overestimated.

Apart from controlling in the wage regression for ability by IQ and other test-based measures, researchers have increasingly used instrumental variables estimates to cope with the ability bias. ${ }^{1}$ Often variables are used as instruments who represent taste for schooling, the discount rate or budget constraints of the individuals. Whereas educational costs (distance-tocollege, tuition costs, liquidity constraints caused by wars, etc.) have been extensively discussed, direct reliance on discount rates is rare ${ }^{2}$. Evans and Montgomery (1994) as well as Chevalier and Walker (1999) suggest that smoking habits are a good predictor for discount rates and use them as instruments for schooling. This goes back to the analysis of Fuchs (1982) who found that health habits like smoking are related to implicit and explicit discount rates.

In this paper we pursue a similar strategy for Austria. Our results are the first IVestimates on returns to education for Austria. Moreover, we use smoking habits at a very early stage in life - age 16 - , an age, where actually schooling decisions are taken.

\section{Schooling choice and ability bias}

In the following we present an adaptation of Card's (1999) model for the choice of schooling. Individuals will invest in schooling until the marginal return in discounted future incomes equates to marginal costs of schooling.

For simplicity assume that individuals earn and pay nothing while in school and get $y=g(S)$ per year thereafter. With $r$ as the discount rate and $S$ as years of education, individuals maximize the discounted present value of future earnings:

\footnotetext{
${ }^{1}$ See Card (1999) for a recent assessment of IV-studies.
} 
(1) $\int_{S}^{\infty} g(S) e^{-r t} d t=\frac{g(S) e^{-r S}}{r}$

In logs we can present the problem as a utility function approach in $\mathrm{y}$ and $\mathrm{S}$

$$
U(y, S)=\log (g(S))-\log r-r S \equiv \log y-h(S)
$$

The optimal level of schooling is defined by the first order condition

(3) $\frac{g^{\prime}(S)}{g(S)}=h^{\prime}(S)$

Marginal returns and marginal costs can be individual specific and be determined by observable characteristics vectors $\mathrm{X}$ and $\mathrm{Z}$.

(4) $\quad \frac{g^{\prime}(S)}{g(S)}=b_{i}-c S ; \quad c \geq 0 ; \quad b_{i}=X_{i} \beta+\xi_{i}$

(5) $\quad h^{\prime}(S)=r_{i} ; \quad r_{i}=Z_{i} \gamma+\eta_{i}$

Here, marginal returns decline with schooling, whereas marginal costs are determined by the individual discount rate $r_{i}$ - directly from (2). We get an explicit solution for the optimal level of schooling:

(6) $\quad S_{i}^{*}=\frac{b_{i}-r_{i}}{c}=X_{i} \tilde{\beta}+Z_{i} \tilde{\gamma}+v_{i}$

A typical Mincerian earnings function with schooling and age as a proxy for work experience would look like

(7) $\quad \log y=\alpha_{0}+\alpha_{1} S_{i}+\alpha_{2}$ age $_{i}+\alpha_{3}$ age $_{i}^{2}+\varepsilon_{i}$

The potential ability bias is now evident because individuals base their schooling decision on individual returns $b_{i}$ in equation (4). If $b_{i}$ has a direct - positive - influence on earnings,

\footnotetext{
${ }^{2}$ Belzil and Hansen (1999) use a dynamic programming model to look at subjective discount rates.
} 
OLS estimates will be biased upwards. The available information on smoking habits gives us an instrumental variables strategy, because smoking is highly correlated with the discount rate, but it does not influence earnings prospects directly, i. e. smoking is part of $\mathrm{Z}$ but not of $\mathrm{X}$. Explaining schooling only by $\mathrm{Z}$, therefore, gives us variation in schooling which is orthogonal to ability which eliminates the ability bias.

Fuchs (1982) found that health habits like smoking are correlated with schooling even controlling for income. ${ }^{3}$ Moreover, he showed that the time preference rate - obtained by a questionnaire with hypothetical situations involving different sums of money at different points in time - correlated positively with smoking habits, even controlling for schooling. The exclusion restriction - why smoking has no direct influence on earnings - is impossible to prove directly. Ault et al (1991) present evidence that smokers are not more absent from work than non-smokers. On the other hand, Levine et al (1997) show for NLSY data that smokers do in fact have between $4-8 \%$ lower wages. Because of evident collinearity between smoking and schooling variables this is not a conclusive test of the exclusion restriction. Moreover, in our empirical analysis we use smoking at age 16, which should in any case be uncorrelated with current earnings.

\section{Data and results}

We use male workers from the Austrian Mikrozensus 1997 - a quarterly 1\% sample of the Austrian population. ${ }^{4}$ We use the parsimonious specification (7) for estimation, which includes no potentially endogenous regressors except schooling. Wages are net hourly wages. Table 1 presents OLS results along with several variants of instrumental variables estimates. The OLS model yields a return to education of 5.6\% per year, which is somewhat lower than comparable results for Austria, because we use age here instead of potential experience.

In column (2) we use information about smoking habits at age 16 of the individual to construct a dummy instrumental variable for years of schooling. $24.8 \%$ of males smoked at that age. Returns to education are lower, but imprecisely estimated. Having smoked at age 16 reduces educational attainment by 0.44 years. As our sample contains different cohorts, and information about smoking risks was not so widespread in the earlier years we proceed by introducing a cohort dummy for those born after 1952 and interact it with the smoking

\footnotetext{
${ }^{3}$ Evans and Montgomery (1994) present results for larger data sets as Fuchs (1982) used and strongly confirm his findings.

${ }^{4}$ See Fersterer and Winter-Ebmer (1999) for a more comprehensive analysis of returns to education in Austria.
} 
indicator. ${ }^{5}$ Now we get a return to education of $5.3 \%$ - very close to the OLS result - which is now very precisely estimated (column (3)). Whereas teenage smokers who were born before 1952 have 0.22 less years of schooling, smokers born after 1952 quit schooling 0.53 years earlier - always compared to non-smokers. As more information on smoking risks was available, the decisions of the younger cohorts are more likely to reflect discount rate differences.

A major problem of the instrumental variables approach is that smoking habits could in turn be caused by education itself. More highly educated individuals could have more information and therefore refrain from smoking. This problem is mitigated because we use age 16 as our smoking indicator, an age where most workers were still in school. Moreover, if there is a knowledge effect of education on smoking behavior, it should show up in changes in smoking among those with more education after age 16. For those who acquire more education but do not change smoking behavior, the knowledge effect must be limited. ${ }^{6}$ In columns (4) and (5) we therefore concentrate on persons who did not change their smoking habits since age 16. Regardless of the inclusion of cohort interactions, we get a return to education of $5 \%$ which is 10 percent below the OLS return.

For comparison, in columns (6) and (7) we present results using current smoking behavior as instruments. Here, five indicators for smoking intensity ${ }^{7}$ are available. Using current smoking results in considerably higher returns to education. For several reasons these results are not reliable. If smoking is a normal good, current smoking can be influenced by current income. As shown by Levine et al (1997) (current) smokers may face lower wages, thus invalidating the exclusion restriction. Finally, current smoking behavior is not necessarily related to the schooling decision taken many years in the past. In fact, the over-identification test shown at the bottom of Table 1 rejects instrumental validity clearly in both cases. This is not the case for the other instruments: in columns (3) and (5) the over-id test cannot reject the null of validity of the instruments.

In the bottom panel we also present further information concerning our instrumental variables estimates. The marginal $\mathrm{R}^{2}$ gives the marginal contribution of our instrument(s) to $\mathrm{R}^{2}$ after including the other exogenous variables. The marginal $\mathrm{R}^{2}$ between 0.008 and 0.034 is relatively low, but F-tests show that the instruments are highly significant in all first stage regressions. Finally a Hausman exogeneity test is performed to check if the IV-results are

\footnotetext{
${ }^{5}$ The dummy for 1952 coincides also with the lengthening of compulsory schooling in 1966 from 8 to 9 years. We experimented also with other dates and two cohort interactions, and got very similar results.

${ }^{6}$ See also Evans and Montgomery (1994, p. 24).

${ }^{7}$ Daily, regularly, from time to time, former smoker, non-smoker. Similar results were also received by using daily consumption of cigarettes as instruments.
} 
significantly different from the OLS estimates. In all cases except column (6) they are not significantly different.

\section{Interpretation}

In our instrumental variables estimates we find slightly lower returns to education in Austria as compared to OLS. This is as expected, if IV methods are to correct for ability bias. Other researchers using also smoking as an instrument find slightly higher (Evans and Montgomery, 1994) and substantially higher returns (Chevalier and Walker, 1999). In some studies higher IV returns are reconciled by arguing that the instrument affects schooling only at the lower end of the schooling distribution (Card, 1999, Ichino and Winter-Ebmer, 1998), ${ }^{8}$ i.e. a Local Average Treatment Effect interpretation of IV estimates (Imbens and Angrist, 1994). This would mean that IV is measuring the returns to education for those people who change educational attainment in case they have a higher (lower) discount rate (the compliers). But this does not necessarily mean that we are measuring returns for individuals with inherently high discount rates and that we should expect, therefore, high returns. To be specific: IV measures the return to education by comparing wage levels of low and high discount rate individuals and dividing by the schooling difference of the two groups.

There is one problem which might impair this interpretation. If the discount rates are sensible to borrowing constraints, individuals from low income families might have higher discount rates. For a fifth of our sample we have information on parental background. We included four dummies for father's education in the wage equation to control for parental background. In a regression corresponding to our preferred specification (column (5) in Table 1) we get returns of 0.058 (0.033 standard errors), very close to the results without family background. ${ }^{9}$ Controlling for family background, therefore, does not change our basic conclusions, that ability bias is not a big problem in Austria.

\footnotetext{
${ }^{8}$ See Ichino and Winter-Ebmer (1999) for an attempt to bound returns to education from below and above by using different instruments.

${ }^{9}$ Most other specifications are imprecisely estimated because of low sample size.
} 


\section{References}

Ault, Richard W. et al (1991): Smoking and Absenteeism, Applied Economics 23, 743-754.

Belzil, Christian and Jörgen Hansen (1999): Subjective Discount Rates, Intergenerational Transfers and the Return of Schooling, IZA Working Paper 60, Bonn.

Card, David (1999): The Causal Effect of Education on Earnings, in: Orley Ashenfelter and David Card (eds.), Handbook of Labor Economics, Volume 3, Amsterdam (NorthHolland), forthcoming.

Chevalier, Arnaud and Ian Walker (1999): Further Results on the Returns to Education in the $U K$, mimeo, University of Warwick.

Evans, William N. and Edward Montgomery (1994): Education and Health: Where There's Smoke There's an Instrument, WP 4949, NBER.

Fersterer, Josef and Rudolf Winter-Ebmer (1999): Are Austrian Returns to Education Falling over Time? DP 2313, Centre for Economic Policy Research, London.

Fuchs, Victor R. (1982): Time Preference and Health: An Exploratory Study, in: Fuchs, Victor R. (ed.), Economic Aspects of Health, Chicago: University of Chicago Press.

Ichino, Andrea and Rudolf Winter-Ebmer (1998): The Long-Run Educational Cost of World War II: An Example of Local Average Treatment Estimation, WP 9802, University of Linz.

Ichino, Andrea and Rudolf Winter-Ebmer (1999): Lower and Upper Bounds of Returns to Schooling: An Exercise in IV Estimation with Different Instruments, European Economic Review 43/4-6, 889-902.

Imbens, Guido and Joshua D. Angrist (1994): Identification and Estimation of Local Average Treatment Effects, Econometrica 62, 467-475.

Levine, Phillip B., Gustafson, Tara A. and Ann D. Velenchik (1997): More Bad News for Smokers? The Effects of Cigarette Smoking on Wages, Industrial and Labor Relations Review 50, 3, 493-509.

Oosterbeek, Hessel and Hans van Opham (1999): Schooling Choices: Preferences, Discount Rates, and Rates of Return, mimeo, University of Amsterdam. 
Table 1: Instrumental variable estimates 1997

OLS

Two-Stage Least Square Estimates

\begin{tabular}{|c|c|c|c|c|c|c|c|}
\hline \multirow[t]{2}{*}{ Instruments used } & \multirow[b]{2}{*}{ (1) } & \multirow{2}{*}{$\begin{array}{l}\text { Smoked at } \\
\text { Age } 16 \\
\text { (2) }\end{array}$} & \multirow{2}{*}{$\begin{array}{l}\text { Smoked at Age 16, } \\
\text { born after } 1952 \\
\text { Interaction } \\
\text { (3) }\end{array}$} & \multirow{2}{*}{$\begin{array}{l}\text { Smoked at } \\
\text { Age } 16^{\text {a) }} \\
\text { (4) }\end{array}$} & \multirow{2}{*}{$\begin{array}{l}\text { Smoked at Age 16, } \\
\text { born after } 1952 \\
\text { Interaction a) } \\
\text { (5) }\end{array}$} & \multirow{2}{*}{$\begin{array}{c}\text { Current Smoking } \\
\text { b) } \\
\text { (6) }\end{array}$} & \multirow{2}{*}{$\begin{array}{l}\text { Current Smoking, } \\
\text { born after 1952 } \\
\text { Interaction b) } \\
\text { (7) }\end{array}$} \\
\hline & & & & & & & \\
\hline Years of Schooling & $\begin{array}{c}0.056 \\
(0.002)\end{array}$ & $\begin{array}{c}0.034 \\
(0.030)\end{array}$ & $\begin{array}{c}0.053 \\
(0.012)\end{array}$ & $\begin{array}{c}0.049 \\
(0.021)\end{array}$ & $\begin{array}{c}0.050 \\
(0.012)\end{array}$ & $\begin{array}{c}0.084 \\
(0.015)\end{array}$ & $\begin{array}{c}0.070 \\
(0.010)\end{array}$ \\
\hline Age & $\begin{array}{c}0.028 \\
(0.003)\end{array}$ & $\begin{array}{c}0.030 \\
(0.004)\end{array}$ & $\begin{array}{c}0.028 \\
(0.003)\end{array}$ & $\begin{array}{c}0.029 \\
(0.004)\end{array}$ & $\begin{array}{c}0.028 \\
(0.004)\end{array}$ & $\begin{array}{c}0.024 \\
(0.003)\end{array}$ & $\begin{array}{c}0.026 \\
(0.003)\end{array}$ \\
\hline $\operatorname{Age}^{2} \times 100$ & $\begin{array}{r}-0.021 \\
(0.004)\end{array}$ & $\begin{array}{l}-0.024 \\
(0.005)\end{array}$ & $\begin{array}{c}-0.021 \\
(0.004)\end{array}$ & $\begin{array}{l}-0.023 \\
(0.006)\end{array}$ & $\begin{array}{l}-0.023 \\
(0.005)\end{array}$ & $\begin{array}{l}-0.015 \\
(0.005)\end{array}$ & $\begin{array}{l}-0.018 \\
(0.004)\end{array}$ \\
\hline Constant & $\begin{array}{c}3.370 \\
(0.055)\end{array}$ & $\begin{array}{c}3.560 \\
(0.020)\end{array}$ & $\begin{array}{c}3.388 \\
(0.117)\end{array}$ & $\begin{array}{c}3.423 \\
(0.184)\end{array}$ & $\begin{array}{c}3.421 \\
(0.117)\end{array}$ & $\begin{array}{c}3.119 \\
(0.145)\end{array}$ & $\begin{array}{c}3.243 \\
(0.104)\end{array}$ \\
\hline R-sq. adj. & 0.276 & 0.254 & 0.276 & 0.266 & 0.266 & 0.237 & 0.267 \\
\hline \multicolumn{8}{|l|}{ First Stage } \\
\hline Marginal R-square ${ }^{c}$ & & 0.008 & 0.025 & 0.010 & 0.028 & 0.016 & 0.034 \\
\hline Hausman (p-value) & & 0.314 & 0.861 & 0.820 & 0.710 & 0.054 & 0.147 \\
\hline Overid (p-value) & & -- & 0.351 & -- & 0.992 & 0.001 & 0.002 \\
\hline \# Obs. & 4302 & 4302 & 4302 & 3537 & 3537 & 4302 & 4302 \\
\hline
\end{tabular}

Note: Standard errors in parenthesis

a) without former smokers

b) The following indicators are used: daily, regularly, from time to time, former smoker, non-smoker

c) F-tests of joint significance of the instruments are highly significant in all cases. 